\title{
Synthesis, Spectroscopic Characterization, and Biological Activities of New Binuclear Co(II), Ni(II), Cu(II), and Zn(II) Diimine Complexes
}

\author{
Ahmed Gaber ${ }^{1,2} \oplus$, Arafa A. M. Belal ${ }^{3}$, Ibrahim M. El-Deen ${ }^{3}$, Nader Hassan ${ }^{3}$, Rozan Zakaria ${ }^{3}$, \\ Walaa F. Alsanie ${ }^{2,4}$, Ahmed M. Naglah ${ }^{5,6}$ (D) and Moamen S. Refat ${ }^{7, *(D)}$ \\ 1 Department of Biology, College of Science, Taif University, P.O. Box 11099, Taif 21944, Saudi Arabia; \\ a.gaber@tu.edu.sa \\ 2 Center of Biomedical Sciences Research (CBSR), Taif University, P.O. Box 11099, Taif 21944, Saudi Arabia; \\ w.alsanie@tu.edu.sa \\ 3 Department of Chemistry, Faculty of Science, Port Said University, Port Said 42511, Egypt; \\ a.belal@psu.edu.eg (A.A.M.B.); i.eldeen@psu.edu.eg (I.M.E.-D.); n.hassan@psu.edu.eg (N.H.); \\ r.zakaria@psu.edu.eg (R.Z.) \\ 4 Department of Clinical Laboratories Sciences, The Faculty of Applied Medical Sciences, Taif University, \\ P.O. Box 11099, Taif 21944, Saudi Arabia \\ 5 Drug Exploration \& Development Chair (DEDC), Department of Pharmaceutical Chemistry, College of \\ Pharmacy, King Saud University, Riyadh 11451, Saudi Arabia; anaglah@ksu.edu.sa \\ 6 National Research Centre, Department of Peptide Chemistry, Chemical Industries Research Division, Dokki, \\ Cairo 12622, Egypt \\ check for \\ 7 Department of Chemistry, College of Science, Taif University, P.O. Box 11099, Taif 21944, Saudi Arabia \\ * Correspondence: moamen@tu.edu.sa
}

Citation: Gaber, A.; Belal, A.A.M.; El-Deen, I.M.; Hassan, N.; Zakaria, R.; Alsanie, W.F.; M. Naglah, A.; Refat, M.S. Synthesis, Spectroscopic Characterization, and Biological Activities of New Binuclear Co(II), $\mathrm{Ni}(\mathrm{II}), \mathrm{Cu}(\mathrm{II})$, and $\mathrm{Zn}$ (II) Diimine Complexes. Crystals 2021, 11, 300. https://doi.org/10.3390/cryst11030300

Academic Editor: Alexander S. Novikov

Received: 21 February 2021

Accepted: 15 March 2021

Published: 17 March 2021

Publisher's Note: MDPI stays neutral with regard to jurisdictional claims in published maps and institutional affiliations.

Copyright: (c) 2021 by the authors. Licensee MDPI, Basel, Switzerland. This article is an open access article distributed under the terms and conditions of the Creative Commons Attribution (CC BY) license (https:// creativecommons.org/licenses/by/ $4.0 /)$.
Abstract: Metal-ligand complexes have attracted major interest due to their potential medical applications as anticancer agents. The work described in the current article aimed to synthesize, spectroscopic, thermal, and biological studies of some metal-diimine complexes. A diimine ligand, namely 2-\{[2-(4-chlorophenyl)-2-hydroxyvinyl]-hydrazonomethyl\}phenol (diim) was prepared via the reaction of $p$-chlorophenacyl bromide with hydrazine hydrate in ethanol, then condensation was completed with 2-hydroxybenzaldehyde in acetic acid. The Co(II), Ni(II), Cu(II), and Zn(II) complexes were prepared with a metal:ligand stoichiometric ratio of (2:1). ${ }^{1} \mathrm{H}-\mathrm{NMR}, \mathrm{UV}-\mathrm{Vis}, \mathrm{FTIR}$ spectroscopic data, molar conductivity measurements, and microanalytical data (carbon, hydrogen, nitrogen, and halogen) were used for characterization of the formed ligand and its metal complexes. It was found that the diimine ligand act as tetradentate fashion. The non-electrolytic character for all the complexes was proved by molar conductivity. The first metal atom of the synthesized binuclear diimine complexes coordinates with the nitrogen of hydrazine group and oxygen of $\mathrm{OH}$ group. While, the second metal atom coordinates with the other nitrogen atom of the hydrazine group and oxygen of phenolic group. All the synthesized metal complexes have a six-coordinated except for $\mathrm{Zn}$ (II) has four-coordinated. Thermogravimetric analysis and its differential analysis were done to discuss the thermal degradation of the free ligand and its metal complexes. Molecular docking calculation showed that the diimine ligand is a good inhibitor for breast cancer $3 h b 5$ and $401 v$ kidney cancer proteins. Additionally, these compounds were evaluated as antibacterial and antifungal agents.

Keywords: diimine; complex; thermogravimetric; antimicrobial; molecular docking

\section{Introduction}

Hydrazone compounds include a $\mathrm{C}=\mathrm{N}$ bond, in which the nitrogen atom has lone pair of electrons (Scheme 1). It can be concluded that nitrogen atoms have nucleophilic character (Figure 1) [1]. These compounds are relevant to ketones and aldehydes as they have a $\mathrm{R}_{1} \mathrm{R}_{2} \mathrm{C}=\mathrm{NNH}_{2}$ structure [2-5]. According to a literature survey, hydrazones and their derivatives have various pharmacological and biological activities [6,7], as well 
as significant utility for synthesizing heterocyclic compounds [8]. Hydrazones can be classified in two ways: (a) as monohydrazones, dihydrazones and trihydrazone according to the number of hydrazone groups (Figure 2) or (b) as bi-, tri-, tetra-, penta-, hexa-, and octa-dentate according to the number of functional groups that can participate in complexation reactions [9]. The metal complexation between hydrazones and different metal ions is dependent on the nature of the metal ion, the basicity of the medium during the reaction, the anion of the salt, and the bonding position of hydrazone compounds [9]. It can be concluded that hydrazones can react as ketones (Scheme 2 path a) or enols (Scheme 2 path b) [10]. The capability of Schiff base ligands to act as chelates and their ability to coordinate with various metal ions through the nitrogen of the imine group and the oxygen of the carbonyl group has made them critical reagents in the coordination chemistry area [11]. These transition metal Schiff base complexes display diverse structural features and, in some instances, exhibit interesting antifungal, antibacterial, catalytic, and luminescence properties [12-14]. The existence of various binding positions in Schiff base ligands makes them good chelators that enhance the luminescence behavior for their formed complexes, especially the binuclear ones $[15,16]$. Until now, to the best of our knowledge no work on the condensation process of 2-hydroxybenzaldehyde and 1-(4chlorophenyl)-2-hydrazinoethanol has been reported. Therefore, our study described in this article aimed to synthesize, spectroscopically characterize, and perform structural, thermogravimetric, and antimicrobial studies of a few binuclear complexes of Co(II), $\mathrm{Ni}(\mathrm{II}), \mathrm{Cu}(\mathrm{II})$, and $\mathrm{Zn}(\mathrm{II})$ with the tetradentate Schiff base ligand 2-\{[2-(4-chlorophenyl)-2hydroxyvinyl]-hydrazonomethyl\}-phenol.<smiles>[R]C([R2])=O</smiles>

Scheme 1. General formation and formula of hydrazines.

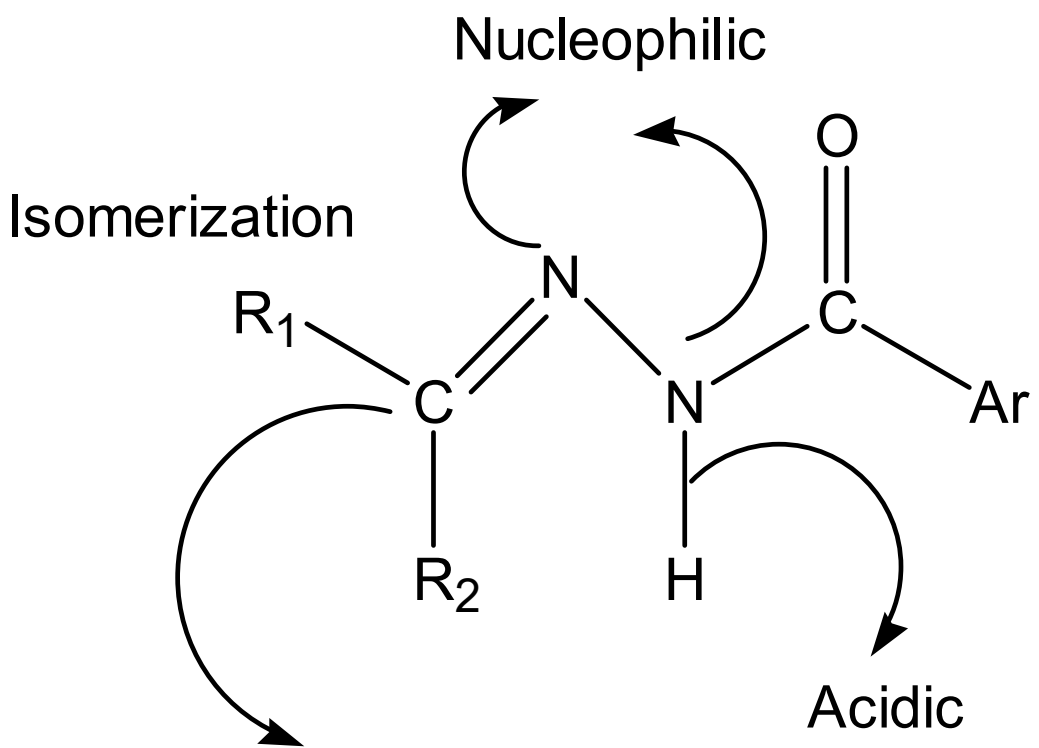

\section{Nucleophilic \& Electrophilic}

Figure 1. The structural and functional diversity of the hrdrazone group. 


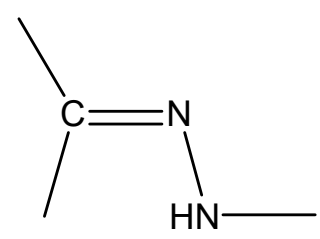

a

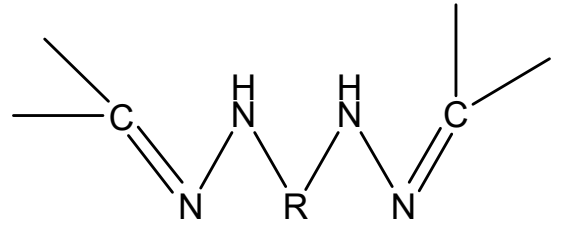

b

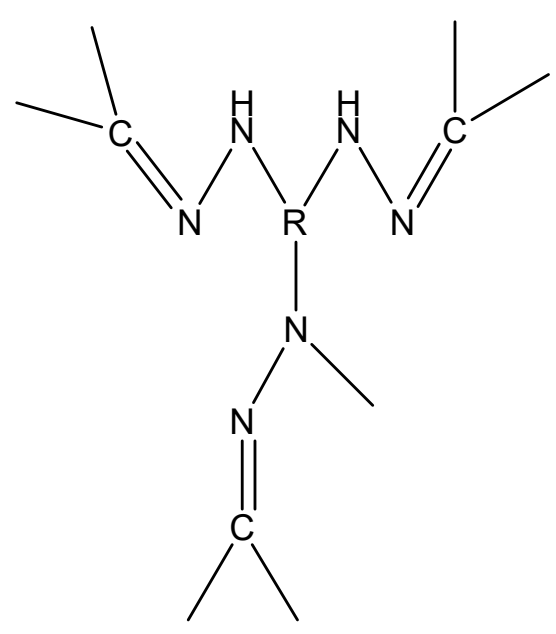

C

Figure 2. Structure representation of mono-(a), di-(b) and tri-(c) hydrazone ligands.<smiles></smiles><smiles>C=NNC(C)=O</smiles>

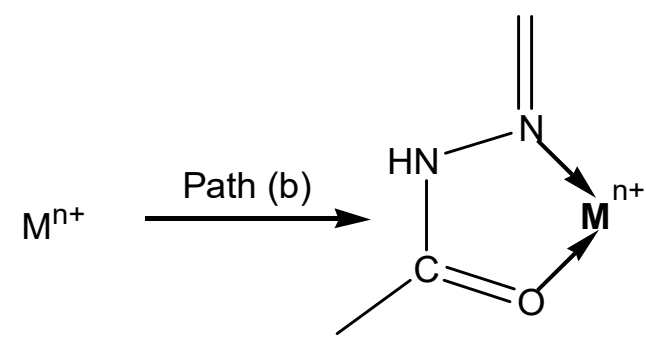

Scheme 2. The bonding of hydrazone ligands with transition metals (a) enolic, (b) ketonic.

\section{Experimental}

\subsection{Materials and Instruments}

Chemicals were previously checked to verify their purity and analytical grade. A 4010 conductivity meter (Jenway, Staffordshire, UK) was used to measure the conductance of complex solutions $\left(10^{-3} \mathrm{~mol} / \mathrm{cm}^{3}\right.$ in DMF). The percentage of metal in the synthesized metal complexes was determined using the gravimetric method by oxidizing it to the most stable form. A Sherwood Scientific (Cambridge, UK) balance was used in magnetic measurements. A Bruker FT-IR spectrophotometer (BRUKER, Billerica, Massachusetts, USA) was used to record infrared spectra at the range of $\left(4000-400 \mathrm{~cm}^{-1}\right)$. Electronic spectra were recoded using a Unicam UV2UV/Vis spectrophotometer (Thermo Fisher, Waltham, Massachusetts, USA), ${ }^{1} \mathrm{H}-\mathrm{NMR}$ spectra were recorded using a $300 \mathrm{MHz}$ Mercury VX-300 NMR spectrometer (Varian, Crawley, UK), and thermal studies were carried out using a TG/DTG-50H thermo-gravimetric analyzer (Shimadzu, Kyoto, Japan) The elemental analyses were perfoemd on a EL III elemental analyzer (Eltra GmbH, Haan, Germany).

\subsection{Synthesis of diim Ligand}

The ligand 2-\{[2-(4-chlorophenyl)-2-hydroxyvinyl]-hydrazonomethyl\}-phenol (3) was synthesized in two steps. The first step, reaction of $p$-chlorophenacyl bromide (1) with hydrazine hydrate in ethanol gave 1-(4-chlorophenyl)-2-hydrazinoethenol (2). The second step, condensation of hydrazine derivative (2) with 2-hydroxybenzaldehyde in acetic acid under reflux produced the diimine ligand 3 (Scheme 3). 


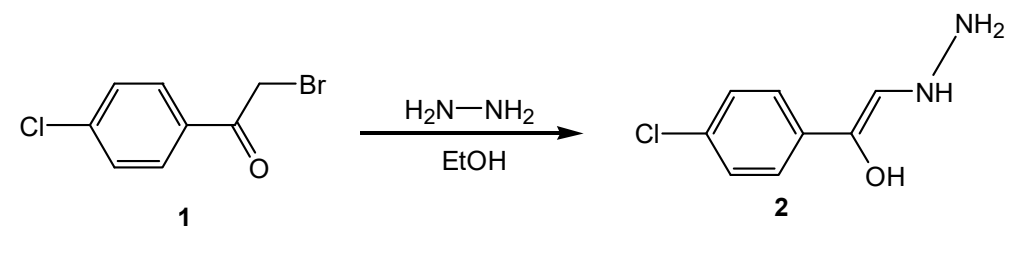<smiles>O=Cc1ccc(C(=O)O)cc1O</smiles>

3

Scheme 3. Synthesis of diim ligand 3.

1-(4-chlorophenyl)-2-hydrazinoethenol (2)

An equimolar solution of $p$-chlorophenacyl bromide $(0.01 \mathrm{M})$ and hydrazine hydrate $(0.01 \mathrm{M})$ prepared in $50 \mathrm{~mL}$ of ethanol was refluxed for $2 \mathrm{~h}$. After that, the mixture was left to cool down and then neutralized with dilute acetic acid. The resulting compound resulted was filtered off, washed with water then recrystallized from ethanol to provide compound 2. Melting point $98^{\circ} \mathrm{C}$; IR $(\mathrm{KBr}) \mathrm{cm}^{-1}=3350-3050(\mathrm{br}-\mathrm{OH}), 3320,3117\left(\mathrm{NH}_{2}\right), 3230(\mathrm{NH})$, 1615, 1605, $1550(\mathrm{C}=\mathrm{C})$, and $1017(\mathrm{C}-\mathrm{O}) ;{ }^{1} \mathrm{H}-\mathrm{NMR}\left(\mathrm{DMSO}_{-} \mathrm{d}_{6}\right) \delta: 3.21\left(\mathrm{~d}, 2 \mathrm{H}, \mathrm{NH}_{2}\right), 4.2$ $(\mathrm{q}, 1 \mathrm{H}, \mathrm{NH}), 7.28-7.44(\mathrm{~m}, 2 \mathrm{H}, \mathrm{Ar}-\mathrm{H}), 7.31(\mathrm{~d}, 1 \mathrm{H}, \mathrm{CH})$ and $14.07(\mathrm{~s}, 1 \mathrm{H}, \mathrm{OH}) \mathrm{ppm}$.

2-\{[2-(4-chlorophenyl)-2-hydroxyvinyl]-hydrazonomethyl\}-phenol (3)

A solution prepared in $30 \mathrm{~mL}$ of acetic acid from a mixture of hydrazine derivative 2 $(0.01 \mathrm{M})$ and 2-hydroxybenzaldehyde was heated under reflux for $2 \mathrm{~h}$, then left to cool down and poured into water. The resulting solid was separated and recrystallized from ethanol to give compound 3. M.P $=155^{\circ} \mathrm{C}$; IR $(\mathrm{KBr}) \mathrm{cm}^{-1} 3449(\mathrm{br}-\mathrm{OH}), 3046(\mathrm{NH}), 1622(\mathrm{C}=\mathrm{N}), 1575$, $1486(\mathrm{C}=\mathrm{C}), 1390$ and $1271(\mathrm{C}-\mathrm{O}) .{ }^{1} \mathrm{H}-\mathrm{NMR}\left(\mathrm{DMSO}_{6} \mathrm{~d}_{6}\right) \delta: 6.997(\mathrm{~s}, 1 \mathrm{H}, \mathrm{CH}=\mathrm{N}), 7.38-7.65$ $(\mathrm{m}, 8 \mathrm{H}, 2 \mathrm{Ar}-\mathrm{H}), 9.01(\mathrm{~s}, 1 \mathrm{H}, \mathrm{OH})$ and $11.16(\mathrm{~s}, 1 \mathrm{H}, \mathrm{NH}) \mathrm{ppm}$. The suggested structural formula for the ligand (diim) was verified by its mass spectrum (Figure 3). The following peaks were recorded $\left(\mathrm{m} / \mathrm{z}^{+}\right) 288,238,181,71$, and 43 that correspond to $\left[\mathrm{C}_{15} \mathrm{H}_{13} \mathrm{~N}_{2} \mathrm{O}_{2} \mathrm{Cl}\right]^{+}$, $\left[\mathrm{C}_{15} \mathrm{H}_{14} \mathrm{~N}_{2} \mathrm{O}\right]^{+},\left[\mathrm{C}_{10} \mathrm{H}_{16} \mathrm{~N}_{2} \mathrm{O}\right]^{+},\left[\mathrm{C}_{3} \mathrm{H}_{8} \mathrm{~N}_{2}\right]^{+}$and $\left[\mathrm{C}_{2} \mathrm{H}_{5} \mathrm{~N}\right]^{+}$ions, respectively, confirming the proposed molecular structure and formula.

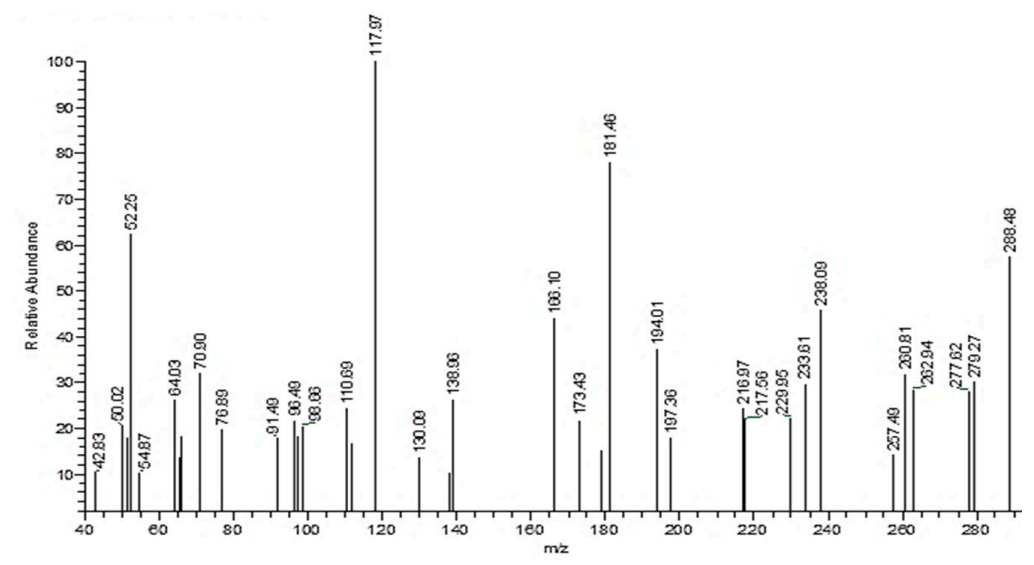

Figure 3. Mass spectrum fragmentation of the diim ligand. 


\subsection{Synthesis of solid $\mathrm{Co}(\mathrm{II}), \mathrm{Ni}(\mathrm{II}), \mathrm{Cu}(\mathrm{II})$, and $\mathrm{Zn}(\mathrm{II})$ diim Complexes}

A hot solution of diim ligand $(1 \mathrm{mmol})$ was prepared in $30 \mathrm{~mL}$ of ethanol containing a few drops of concentrated $\mathrm{NH}_{4} \mathrm{OH}$. Then $2 \mathrm{mmol}$ solutions of the metal(II) salts $\mathrm{CoCl}_{2} \cdot 6 \mathrm{H}_{2} \mathrm{O}, \mathrm{NiCl}_{2} \cdot 6 \mathrm{H}_{2} \mathrm{O}, \mathrm{CuCl}_{2} \cdot 2 \mathrm{H}_{2} \mathrm{O}$ or $\mathrm{ZnCl}_{2}$ were prepared in $20 \mathrm{~mL}$ of ethanol. Each metal solution was added gradually to the former prepared solution. Ammonia solution was used to neutralize the formed mixtures $(\mathrm{pH}=8-9)$, which was then refluxed and well stirred for $2 \mathrm{~h}$ at $75^{\circ} \mathrm{C}$, then evaporated to half its initial volume. The resulting complex was left to cool down until the next day, then separated and washed with a mixture of methanol and diethyl ether. Next, recrystallization was done from methanol and the products were dried using anhydrous $\mathrm{CaCl}_{2}$. Thin-layer chromatography (TLC) was done to confirm the purity.

\subsection{Antibacterial and Antifungal Activities}

The free diim ligand and its metal complexes were dissolved in dimethylsulfoxide (DMSO) to prepare $10 \mathrm{mg} / \mathrm{mL}$ solutions, which were used to measure the inhibition zone to determine the antibacterial activity of these compounds. This activity was determined by the agar well diffusion method and the experiments were repeated three times to be sure of the results. Bacillus subtilis and Staphylococcus aureus were used as examples of Grampositive bacteria, while, E. coli and Proteus vulgaris were used as Gram-negative bacteria. The antifungal activity of the compound was measured against Aspergillus flavus and Candida albicans. The fungal plates were prepared by growing $5 \mathrm{~mL}$ of Sabouraud dextrose broth until $105 \mathrm{CFU} / \mathrm{mL}$ cells were achieved. A sample of $10 \mathrm{mg} / \mathrm{mL}$ was prepared in DMSO, so it was used as standard. Ketoconazole was used as antifungal standard drug.

\section{Results and Discussion}

\subsection{Elemental Analyses and Physical Properties}

The complexes of $\mathrm{Co}(\mathrm{II}), \mathrm{Ni}(\mathrm{II}), \mathrm{Cu}(\mathrm{II})$, and $\mathrm{Zn}(\mathrm{II})$ with 2-\{[2-(4-chlorophenyl)-2hydroxyvinyl]-hydrazonomethyl $\}$ phenol (diim) did not react with the atmosphere and were only dissolved in DMSO and DMF. The conductivity of the complexes measured using a DMSO solution displayed a lower value than the free diim ligand $(7 \mu \mathrm{S})$ which means that all the complexes are characteristically non-electrolytic and that the outer sphere of the coordination is free of anions [17]. The physicochemical analyses results of the diim free ligand and its metal complexes were tabulated and formulated as seen in Table 1. The colored solid synthesized complexes have formulas $\left[\mathrm{Co}_{2}(\operatorname{diim})\left(\mathrm{H}_{2} \mathrm{O}\right)_{4}\left(\mathrm{NH}_{3}\right)_{2}(\mathrm{Cl})_{2}\right](\mathrm{I})$, $\left[\mathrm{Ni}_{2}(\operatorname{diim})\left(\mathrm{H}_{2} \mathrm{O}\right)_{2}\left(\mathrm{NH}_{3}\right)_{4}(\mathrm{Cl})_{2}\right] \cdot 3 \mathrm{H}_{2} \mathrm{O}(\mathrm{II}),\left[\mathrm{Cu}_{2}(\operatorname{diim})\left(\mathrm{H}_{2} \mathrm{O}\right)_{4}\left(\mathrm{NH}_{3}\right)_{2}(\mathrm{Cl})_{2}\right](\mathrm{III})$, and $\left[\mathrm{Zn}_{2}-\right.$ (diim) $\left.\left(\mathrm{NH}_{3}\right)_{2}(\mathrm{Cl})_{2}\right] \cdot 2 \mathrm{H}_{2} \mathrm{O}(\mathrm{IV})$ (Figure 4).

Table 1. Physicochemical data for the diim free ligand and its metal complexes.

\begin{tabular}{ccccccc}
\hline \multirow{2}{*}{ Compounds } & \multirow{2}{*}{ Color } & \multicolumn{5}{c}{ \%Found (\%Calcd.) } \\
\cline { 3 - 7 } & & $\mathbf{C} \%$ & $\mathbf{H} \%$ & $\mathbf{N} \%$ & $\mathbf{C l} \%$ & $\mathbf{M} \%$ \\
\hline diim & Yellow & $62.12(62.40)$ & $4.43(4.54)$ & $9.56(9.70)$ & $12.14(12.28)$ & - \\
\hline I & Brown & $30.86(30.98)$ & $4.12(4.33)$ & $9.54(9.63)$ & $18.19(18.29)$ & $20.16(20.27)$ \\
\hline II & Dark brown & $28.38(28.45)$ & $5.17(5.25)$ & $13.21(13.27)$ & $16.76(16.80)$ & $18.32(18.54)$ \\
\hline III & Orange brown & $30.28(30.49)$ & $4.19(4.26)$ & $9.37(9.48)$ & $17.87(18.00)$ & $21.09(21.51)$ \\
\hline IV & Reddish brown & $32.17(32.26)$ & $3.66(3.79)$ & $9.96(10.03)$ & $18.36(19.04)$ & $23.31(23.42)$ \\
\hline
\end{tabular}




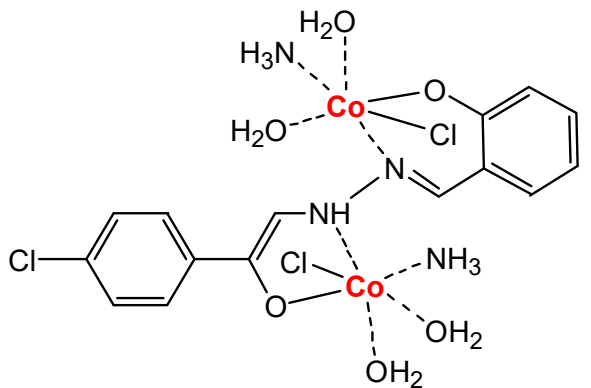

I

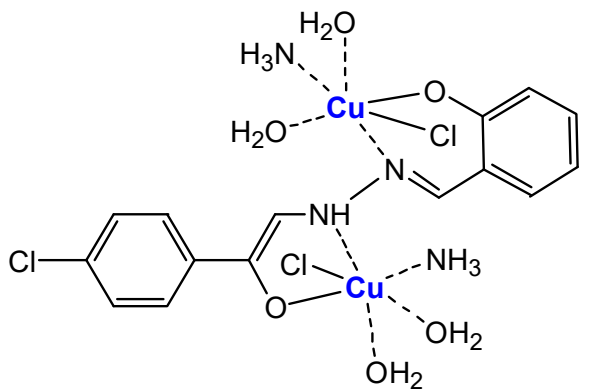

III<smiles></smiles>

II<smiles></smiles>

IV

Figure 4. Proposed structures of 2:1 diim complexes.

\subsection{Infrared Spectral Studies}

The infrared spectra of the diim free ligand and its diim complexes were recorded (Figure 5a,b). It is noted that there are several distinguishing vibration bands that refer to phenolic $(\mathrm{Ar}-\mathrm{OH})$, ketone $(\mathrm{C}=\mathrm{O})$, azomethine $(\mathrm{C}=\mathrm{N})$, phenolic $(\mathrm{C}-\mathrm{O})$, and carbon halogen bond $(\mathrm{C}-\mathrm{Cl})$ functional groups at the frequencies 3449, 3046, 1678, 1622, (1390 \& 1271), and $971 \mathrm{~cm}^{-1}$, respectively. The essential vibration bands of the diim ligand and its corresponding $\mathrm{Co}(\mathrm{II}), \mathrm{Ni}(\mathrm{II}), \mathrm{Cu}(\mathrm{II})$, and $\mathrm{Zn}$ (II) complexes are summarized in Table 2. The medium-strong peak $\left(1678 \mathrm{~cm}^{-1}\right)$ of the carbonyl group found in the free diim ligand disappeared after complexation. This result can be attributed to the tautomerism change of diim ligand from its keto to its enol form in alkaline media through the chelation process (Scheme 4). In the case of the free diim ligand, the very strong peak at $1622 \mathrm{~cm}^{-1}$ refers to $\mathrm{C}=\mathrm{N}$ stretching frequency of the group of azomethine [18]. This stretching absorption band is shifted to a lower frequency $\left(1604-1611 \mathrm{~cm}^{-1}\right)$ in its prepared metal complexes. This result suggests the coordination of the azomethine $\mathrm{C}=\mathrm{N}$ group by a lone pair of electrons on its nitrogen towards the center metal ions. The peak of the phenolic-OH group is shifted to higher frequencies than observed the spectrum of the diim ligand $\left(3449 \mathrm{~cm}^{-1}\right)$. This is because of the hydrogen bond formed among the phenolic oxygen and the nitrogens of azomethine groups (Scheme 4). Regarding the spectra of synthesized complexes I-IV, the broad bands within the $3421-3449 \mathrm{~cm}^{-1}$ range are assigned to the presence of coordinated and uncoordinated water molecules [18]. Average weak absorption peaks found in the range $832-750 \mathrm{~cm}^{-1}$ refer to bending vibrations $\delta\left(\mathrm{H}_{2} \mathrm{O}\right)$ emphasizing the existence of coordinated water. The 1390 and $1271 \mathrm{~cm}^{-1}$ peaks found in the diim ligand spectra refer to $v(\mathrm{C}-\mathrm{O})$ stretching vibrations of the phenolic group. In the case of the vibrational spectra of the metal complexes, these bands disappear or are offset to lower frequencies (13111319 and 1150-1153 $\mathrm{cm}^{-1}$ ) because of the participation of the phenolic oxygens in the coordination of metal ions. In the diim complexes, new peaks appeared at $\sim 3025 \mathrm{~cm}^{-1}$ that can be referred to the $v(\mathrm{NH})$ of $-\mathrm{NH}_{3}$ group confirming the participation of the lone pair of the nitrogen in the $-\mathrm{NH}_{3}$ group of the atom in the coordination reactions. In the spectra of the metal complexes, average vibration peaks are found at a range of $600-518 \mathrm{~cm}^{-1}$ and $466-452 \mathrm{~cm}^{-1}$ that can be assigned to the vibrational motions for $v(\mathrm{M}-\mathrm{O})$ and $v(\mathrm{M}-\mathrm{N})$ 
bands, proving the participation of oxygen and nitrogen atoms of the phenolic, hydroxyl, azomethine, hydrazino groups in coordinating with the metal [18].

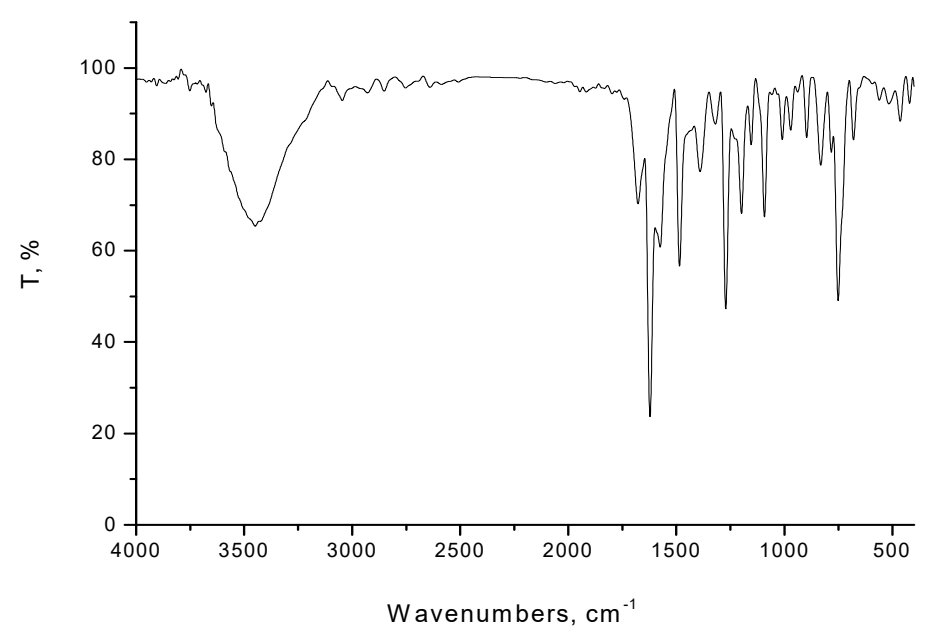

(a)

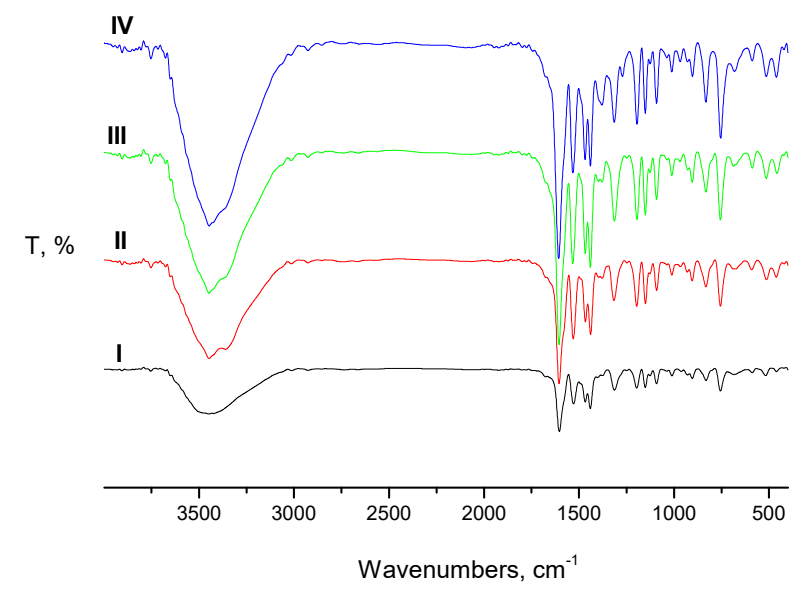

(b)

Figure 5. (a) Infrared spectrum of diim free ligand and (b). Infrared spectra of I: $\mathrm{Co}(\mathrm{II}), \mathrm{II}: \mathrm{Ni}(\mathrm{II})$, III: $\mathrm{Cu}(\mathrm{II})$ and IV: $\mathrm{Zn}(\mathrm{II})$ diim complexes.

Table 2. Data for infrared spectral bands $\left(\mathrm{cm}^{-1}\right)$ for diim ligand and its metal complexes.

\begin{tabular}{cccccccc}
\hline Compounds & $\boldsymbol{v}(\mathbf{O}-\mathrm{H})$ & $\boldsymbol{v}(\mathrm{N}-\mathrm{H})$ & $\boldsymbol{v}(\mathrm{C}=\mathrm{O})$ & $\boldsymbol{v}(\mathrm{C}=\mathrm{N})$ & $\boldsymbol{v}(\mathrm{C}-\mathrm{O})$ & $v(\mathbf{M}-\mathrm{O})$ & $v(\mathbf{M}-\mathrm{N})$ \\
\hline MTSC & 3449 & 3046 & 1678 & 1622 & 1390,1271 & - & - \\
\hline I & 3449 & 3025 & - & 1604 & 1314,1152 & 589,518 & 461 \\
\hline II & 3448 & 3025 & - & 1606 & 1311,1153 & 586,517 & 452 \\
\hline III & 3447 & 3025 & - & 1606 & 1319,1150 & 593,510 & 463 \\
\hline IV & 3421 & 3025 & - & 1611 & 1150 & 600 & 466 \\
\hline
\end{tabular}




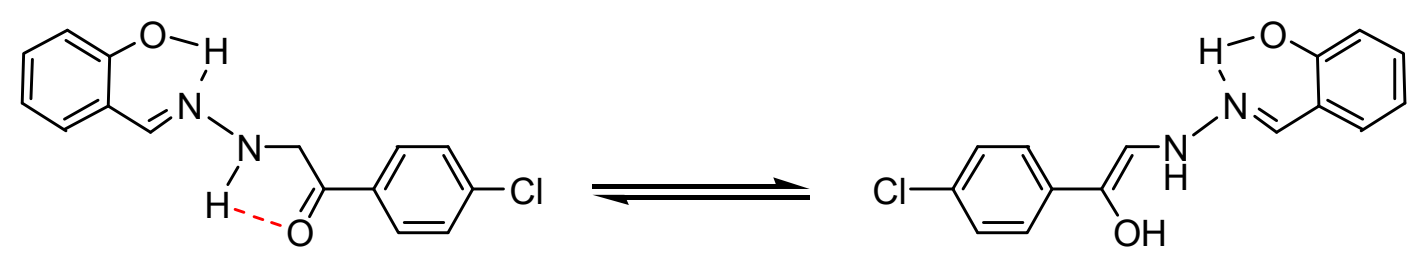

Scheme 4. Tautomerism exchange of the diim ligand keto-enol form in alkaline media.

\subsection{Electronic, Magnetic, and Mass Spectral Studies}

At wavelengths within the range of 300-800 nm, the electronic absorption spectra of diim free ligand and its metal complexes were performed in a DMSO solution (Figure 6). The free diim ligand electronic spectra showed two peaks at 300 and $355 \mathrm{~nm}$ corresponding to $\pi-\pi^{*}$ and $n-\pi^{*}$ electronic transitions [19-21].

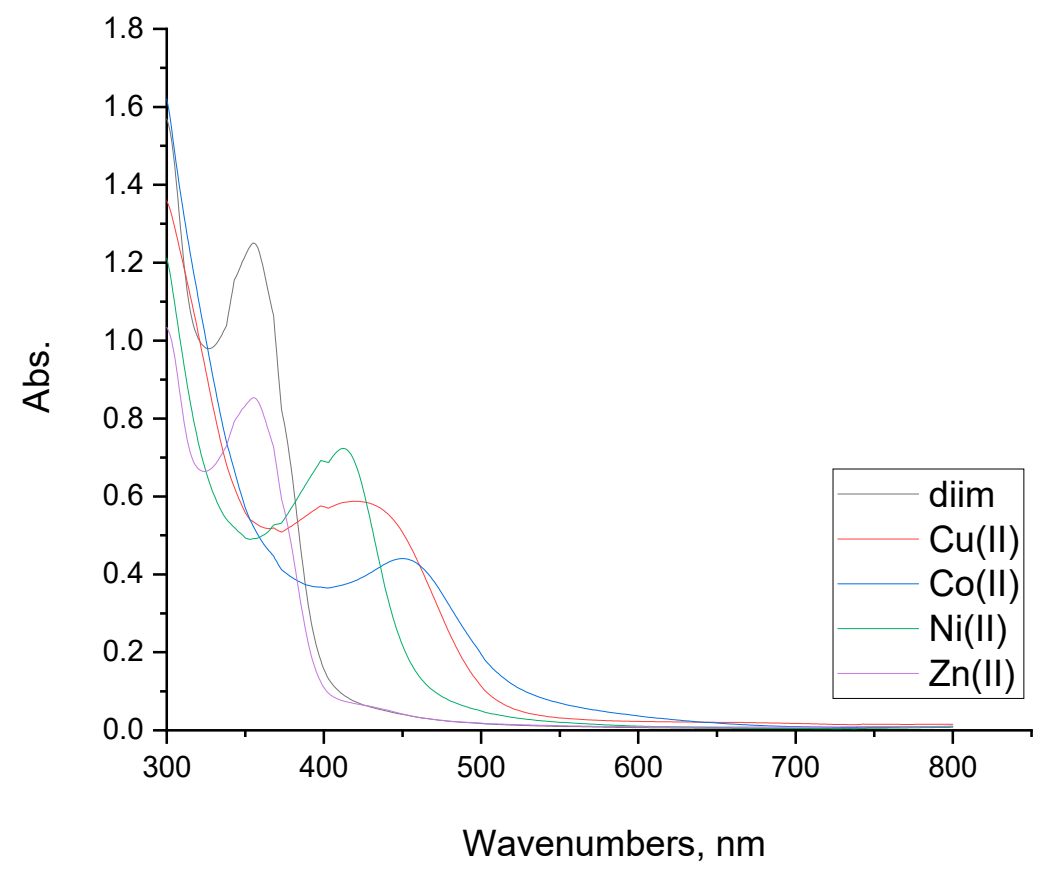

Figure 6. UV-Vis spectra of diim free ligand and its $\mathrm{Co}(\mathrm{II}), \mathrm{Ni}(\mathrm{II}), \mathrm{Cu}(\mathrm{III})$ and $\mathrm{Zn}(\mathrm{II})$ complexes.

The Co(II) complex showed three main bands at 300, 355, and $450 \mathrm{~nm}$ in its UV-Vis absorption spectrum. The first absorption peak referred to the intra-ligand transition of the organic moiety. The second and third electronic transitions referred to ${ }^{4} \mathrm{~T}_{1 \mathrm{~g}} \rightarrow{ }^{4} \mathrm{~T}_{1 \mathrm{~g}}(\mathrm{P})$ and ${ }^{4} \mathrm{~T}_{1 \mathrm{~g}}(\mathrm{~F}) \rightarrow{ }^{4} \mathrm{~T}_{2 \mathrm{~g}}(\mathrm{~F})$, respectively [20,21]. The octahedral geometry of the Co(II) complex was confirmed from the UV-Vis spectrum and the recorded value of its magnetic moment which is 5.10 B.M [20]. The magnetic moment value at room temperature of the cobalt(II) complex is 5.10 B.M which is lower than 5.39 B.M due to anti-ferromagnetic interaction between two Co ions, which confirmed the binuclear nature of the complex. The molecular ion peak of the $\mathrm{Co}$ (II) complex was observed at $m / z=581$, confirming the molecular weight. The mass fragmentation spectrum can be seen in Figure S1.

The electronic spectrum of the $\mathrm{Ni}$ (II) complex was found to have four electronic transition peaks at 300,368, 399, and $410 \mathrm{~nm}$. The first and second peak may be assigned to ligand-to-metal charge-transfer transitions, while the next two transition bands refer to $\mathrm{d}-\mathrm{d}$ transitions of ${ }^{3} \mathrm{~A}_{2 \mathrm{~g}}(\mathrm{~F}) \rightarrow{ }^{3} \mathrm{~T}_{1 \mathrm{~g}}(\mathrm{P})$ and ${ }^{3} \mathrm{~A}_{2 \mathrm{~g}} \rightarrow{ }^{3} \mathrm{~T}_{1 \mathrm{~g}}(\mathrm{~F})$, respectively. The value of $\mathrm{Ni}(\mathrm{II})$ complex magnetic moment was recorded at 2.74 B.M. From these results, the octahedral geometry was confirmed [20,21]. The low magnetic moment value at 2.74 B.M rather than the expected experimental value (3.32 B.M) was attributed to anti-ferromagnetic interaction between two Ni ions, which confirmed the binuclear nature of the complex. The mass 
spectrum of the nickel(II) complex shows its molecular ion peak at $m / z=633$, which is consistent with the proposed molecular weight (Figure S2).

The electronic UV-spectrum of the $\mathrm{Cu}(\mathrm{II})$ complex displayed four electronic peaks at $300,365,395$, and $425 \mathrm{~nm}$. The first two absorption peaks refer to ligand-to-metal chargetransfer transitions. The second two absorption peaks point to ${ }^{2} \mathrm{Eg} \rightarrow{ }^{2} \mathrm{~T}_{2 \mathrm{~g}} \mathrm{~d}-\mathrm{d}$ transitions due to a distorted octahedral geometrical structure of the $\mathrm{Cu}$ (II)-complex $[20,21]$. The $\mathrm{Cu}$ (II) complex has a magnetic moment of 1.66 B.M., confirming the deformed octahedral geometry [21]. The magnetic moment value at room temperature of the copper(II) complex is 1.66 B.M, which is lower than 1.96 B.M (ther expected experimental value) due to antiferromagnetic interactions between two copper ions, which confirmed the binuclear nature of the complex. The mass spectrum of the copper(II) complex shows a molecular ion peak at $m / z=591$, which is consistent with the proposed molecular weight (Figure S3).

The conductivity, microanalytical, and magnetic moment data of the $\mathrm{Zn}$ (II) complex spectrum proved its diamagnetic behavior and tetrahedral geometry $[20,21]$. The molecular ion peak of the $\mathrm{Zn}$ (II) complex was observed at $\mathrm{m} / \mathrm{z}=558$, confirming the molecular weight. The mass fragmentation spectrum can be seen in Figure S4.

\section{4. ${ }^{1} H-N M R$ Spectra Studies}

${ }^{1} \mathrm{H}-\mathrm{NMR}$ spectra for the studied ligand (diim) and its diamagnetic $\mathrm{Zn}(\mathrm{II})$ complex were recorded in DMSO. The studied ligand (diim) shows the following chemical shifts:

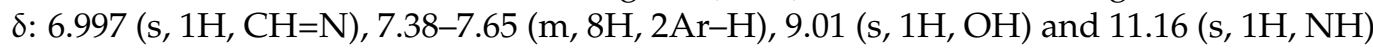
$\mathrm{ppm}$. In the case of $\mathrm{Zn}$ (II) complex nearly all the peaks became weaker and were shifted to downfield positions: $\delta: 3.36\left(\mathrm{~s}, 2 \mathrm{H}, \mathrm{H}_{2} \mathrm{O}\right)$, and 7.39-7.71 $(\mathrm{m}, 8 \mathrm{H}, 2 \mathrm{Ar}-\mathrm{H}) \mathrm{ppm}$. The $\mathrm{HC}=\mathrm{N}$ azomethine, $-\mathrm{NH}$, and $-\mathrm{OH}$ groups protons disappeared after complexation, confirms the coordination site around the $\mathrm{Zn}$ (II) metal ions. A new peak was noticed at $3.36 \mathrm{ppm}$ referring to the protons of water molecules coordinating with the metal ions. The predicted structural formula of the $\mathrm{Zn}$ (II) confirming its tetrahedral geometry as shown in Figure 6 .

\subsection{Thermo Gravimetric Studies}

TG and DrTGA thermal decomposition curves of free diim ligand and its metal complexes [Co(II), $\mathrm{Ni}(\mathrm{II}), \mathrm{Cu}(\mathrm{II})$, and $\mathrm{Zn}(\mathrm{II})]$ under $\mathrm{N}_{2}$ atmosphere with a rate of heating $10^{\circ} \mathrm{C} / \mathrm{min}$ were assigned (Figure $7 \mathrm{a}-\mathrm{e}$ ) and are summarized in Table 3.

\subsubsection{Diim Free Ligand}

The melting point of diim ligand was at $155^{\circ} \mathrm{C}$. Next, it undergoes concurrent degradation. It is found that the ligand decomposition takes place in three main degradation steps. The first degradation phase occurs in the $49-220^{\circ} \mathrm{C}$ temperature range with an observed weight loss equal to $6.25 \%$ (calc. $=5.89 \%$ ). The second and third degradation phases happen in the $220-425{ }^{\circ} \mathrm{C}$ (obs. $=53.75 \%$, calc. $=55.5 \%$ ) and $425-700{ }^{\circ} \mathrm{C}$ temperature range (obs. $=32.5 \%$, calc. $=30.3 \%$ ), respectively. Remaining residue up to $700{ }^{\circ} \mathrm{C}$ was accompanied by a $7.5 \%$ loss in weight (calc. $=8.32 \%$ ). All the thermal fragments in the three stages are organic moieties, which were converted into gaseous phases.

\subsubsection{Cobalt(II) Complex I}

From the thermal degradation curve of $\mathrm{Co}$ (II) complex it was found that it decomposes as follows: The first decomposition phase occurs in the $38-163{ }^{\circ} \mathrm{C}$ temperature range with a $6.7 \%$ observed mass loss (calc. $=6.2 \%$ ) attributable to the loss of coordinated $\mathrm{H}_{2} \mathrm{O}$. The second degradation phase takes place in the $163-470{ }^{\circ} \mathrm{C}$ temperature range with mass a mass loss of $57.1 \%$ (observed, calc. $=55.9 \%$ ) due to chloride, ammonia, nitrogen oxide, and acetylene gas molecule losses, while the third step takes place in the $470-565{ }^{\circ} \mathrm{C}$ temperature range with an observed loss in weight of $4.8 \%$ (calc. $=5.8 \%$ ) that refers to 2 ammonia gas molecule losses. The final residue was pure cobalt metal produced from the reduction of cobalt carbonate to cobalt(II) oxide and it remained stable up to $700{ }^{\circ} \mathrm{C}$. 


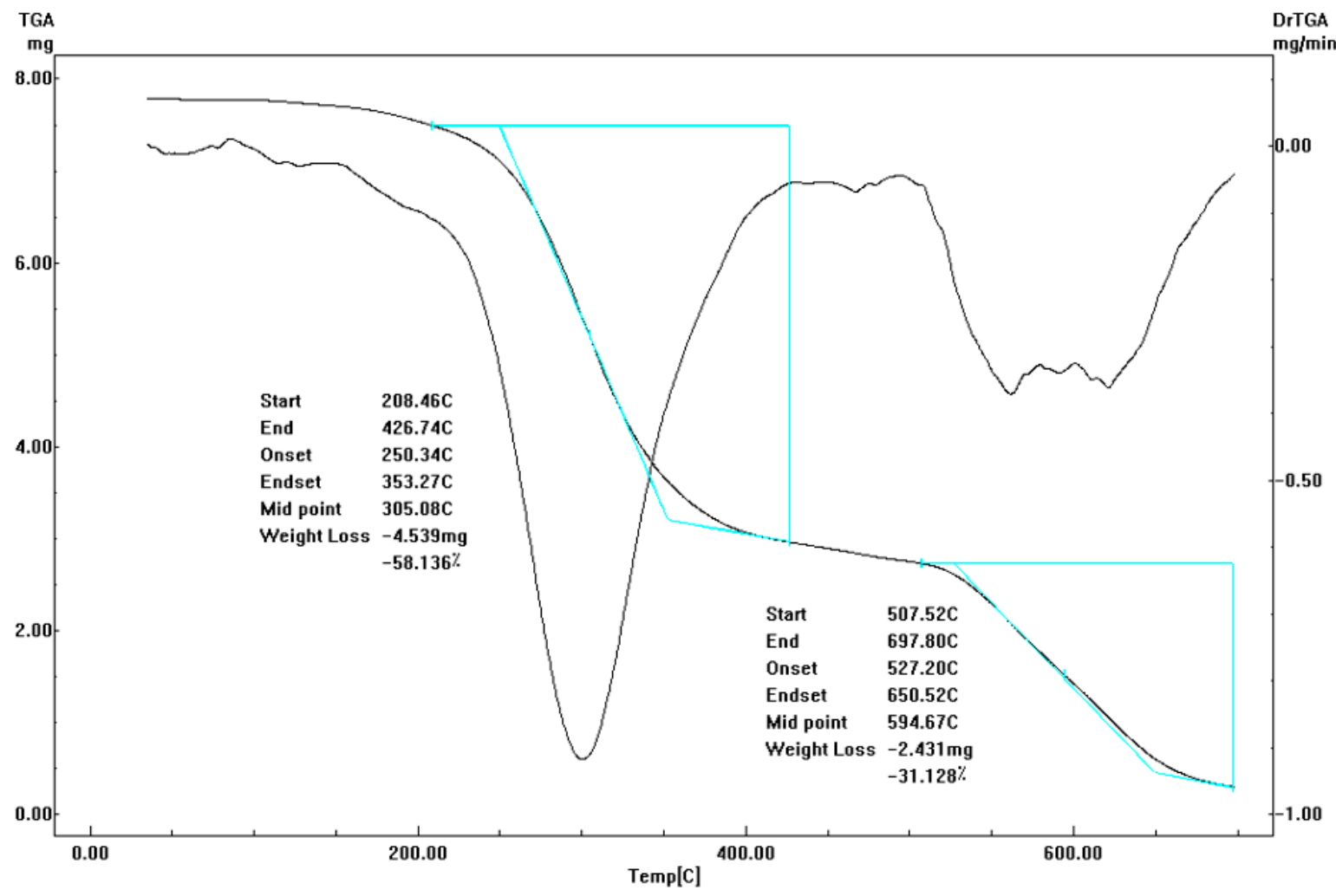

(a)

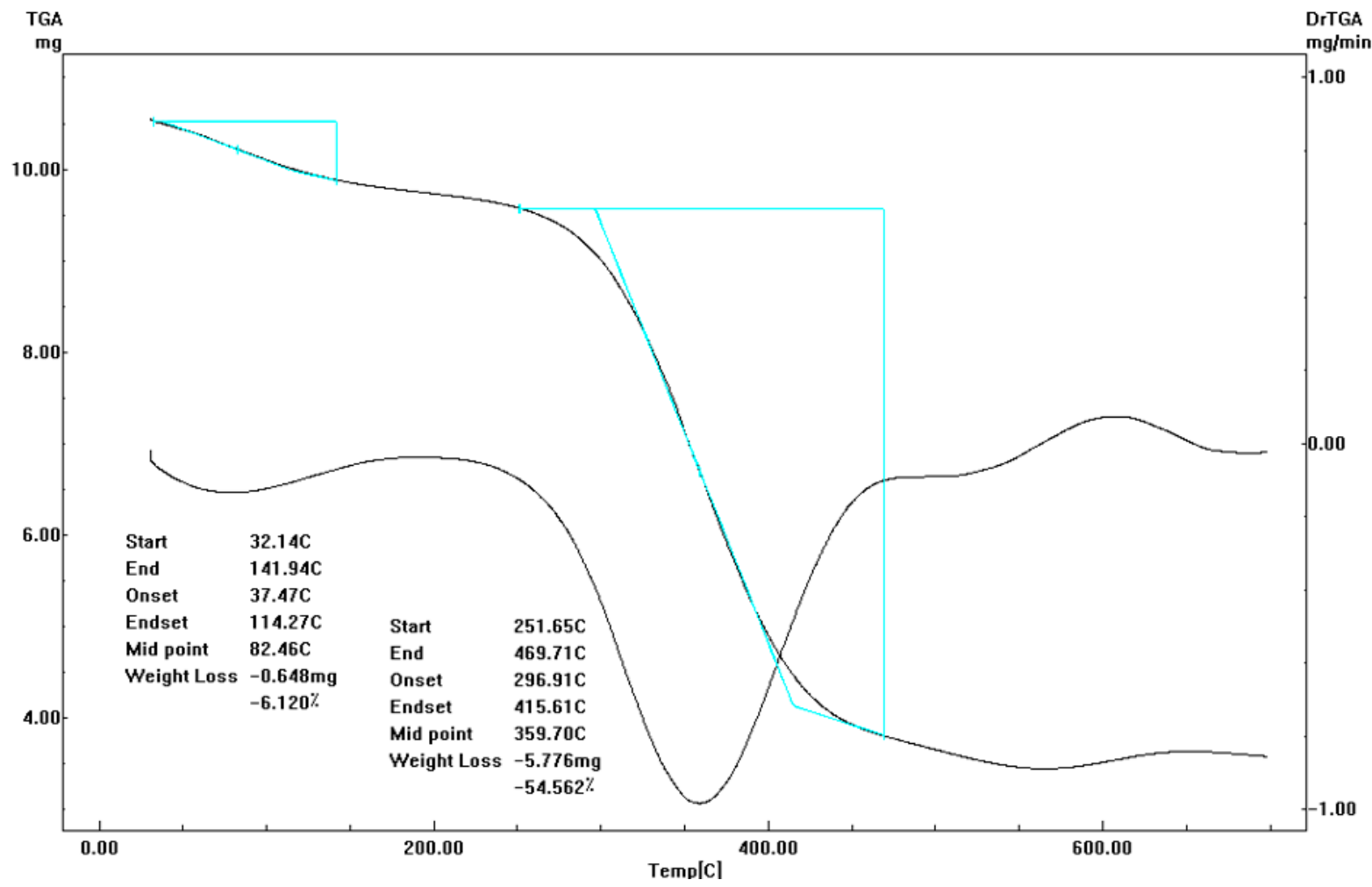

(b)

Figure 7. Cont. 


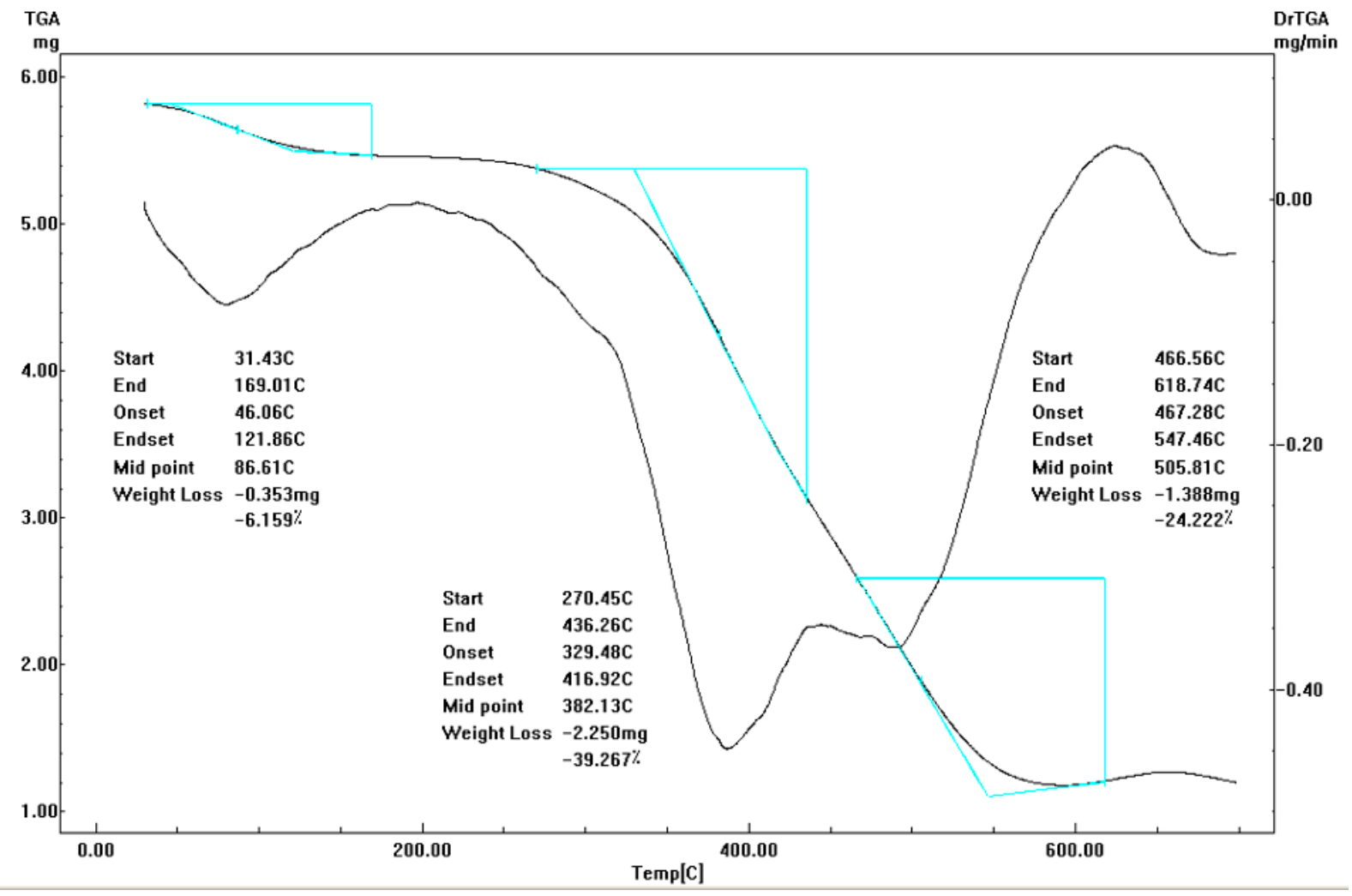

(c)

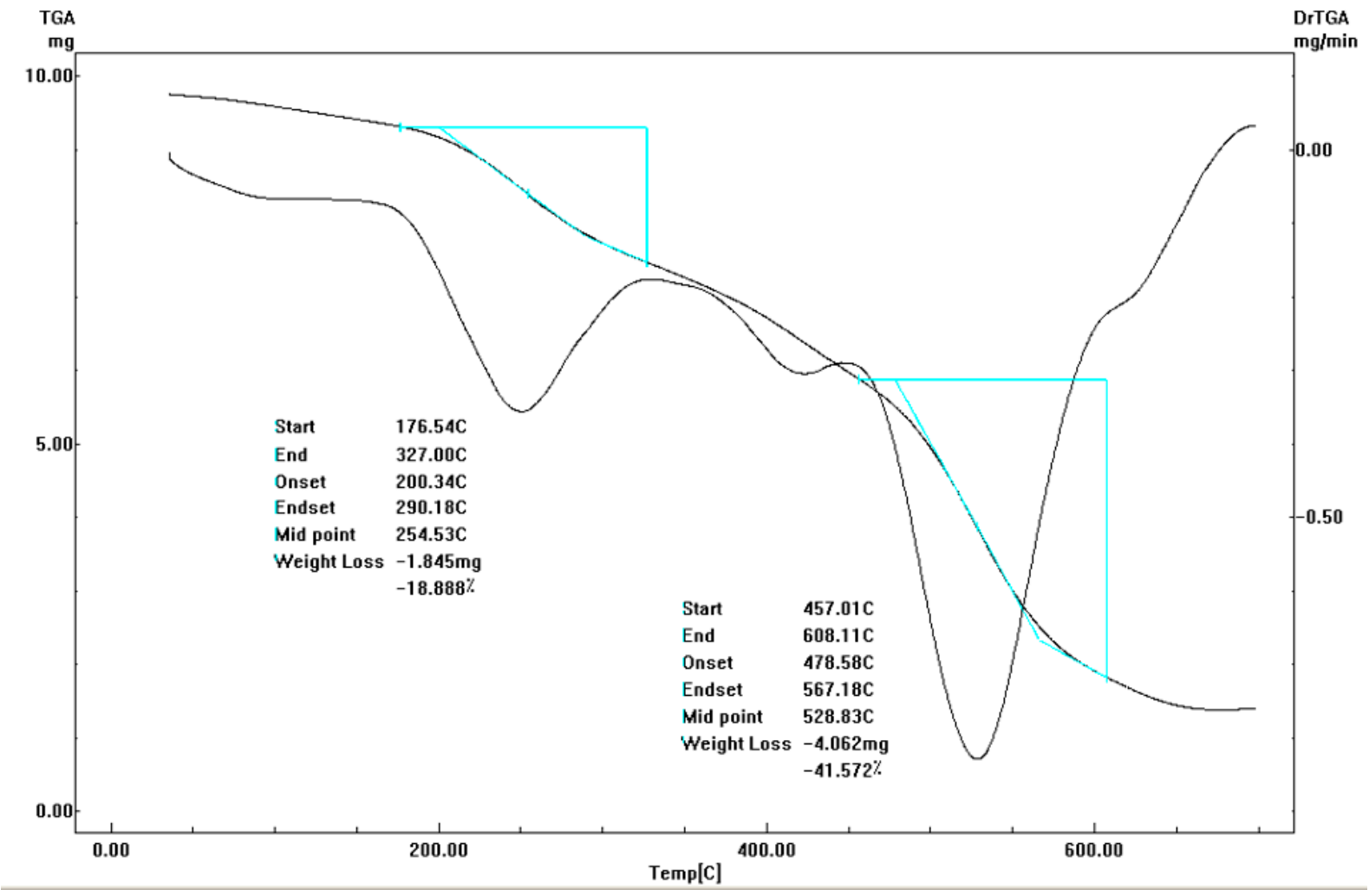

(d)

Figure 7. Cont. 


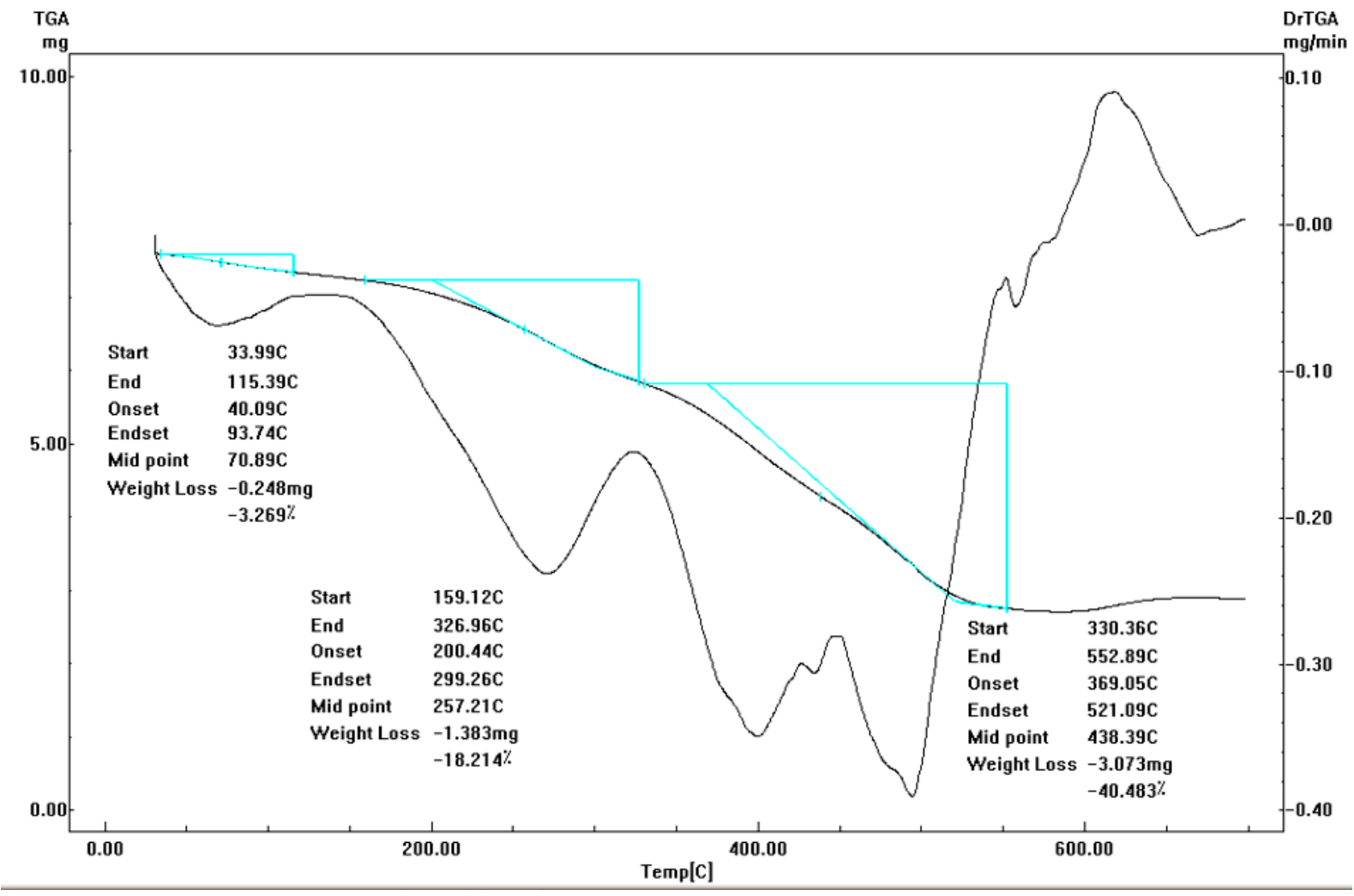

(e)

Figure 7. TGA-DrTGA curves of (a) diim free ligand, (b) cobalt(II) complex, (c) nickel(II) complex, (d) copper(II) complex and (e) zinc(II) complex.

Table 3. Thermo gravimetric data of the diim ligand and its metal complexes.

\begin{tabular}{|c|c|c|c|c|c|}
\hline Compounds & Steps & Temp. Range $/{ }^{\circ} \mathrm{C}$ & DTG Peak $/{ }^{\circ} \mathrm{C}$ & Decompositon Product Assignments & Mass Loss Found (Calc.)\% \\
\hline \multirow{4}{*}{ diim } & $1 \mathrm{st}$ & $49-220$ & 115 & $\mathrm{NH}_{3}$ & $6.25(5.89)$ \\
\hline & 2nd & $220-425$ & 299 & $5 \mathrm{C}_{2} \mathrm{H}_{2}+\mathrm{NO}$ & $53.75(55.5)$ \\
\hline & 3rd & $425-700$ & 560 & $\mathrm{C}_{3} \mathrm{O}+\frac{1}{2} \mathrm{Cl}_{2}$ & $32.5(30.3)$ \\
\hline & residue & 700 & & carbon residue & $7.5(8.32)$ \\
\hline \multirow{4}{*}{ I } & $1 \mathrm{st}$ & $38-163$ & 80 & $2 \mathrm{H}_{2} \mathrm{O}$ & $6.7(6.2)$ \\
\hline & 2nd & $163-470$ & 355 & $\mathrm{NH}_{3}+\mathrm{NO}_{2}+1 \frac{1}{2} \mathrm{Cl}_{2}+6 \mathrm{C}_{2} \mathrm{H}_{2}$ & $57.1(55.9)$ \\
\hline & 3 rd & $470-565$ & 515 & $2 \mathrm{NH}_{3}$ & $4.8(5.8)$ \\
\hline & Residue & $565-700$ & & $2 \mathrm{CoO}+$ carbon residue & $31.4(32.1)$ \\
\hline \multirow{4}{*}{ II } & 1 st & $38-168$ & 80 & \multirow{4}{*}{$\begin{array}{c}2 \mathrm{H}_{2} \mathrm{O}+2 \mathrm{H}_{2} \\
\mathrm{H}_{2} \mathrm{O}+\mathrm{CO}+\mathrm{NH}_{3}+\mathrm{NO}+2 \mathrm{~N}_{2}+3 \mathrm{H}_{2} \\
+1 \frac{1}{2} \mathrm{Cl}_{2} \\
7 \mathrm{C}_{2} \mathrm{H}_{2} \\
2 \mathrm{NiO}\end{array}$} & $7(6.3)$ \\
\hline & 2nd & $168-449$ & 388 & & $41.3(41.1)$ \\
\hline & 3rd & $449-586$ & 496 & & $29.3(28.8)$ \\
\hline & Residue & $586-700$ & & & $22.4(23.6)$ \\
\hline \multirow{4}{*}{ III } & $1 \mathrm{st}$ & $40-170$ & 85 & $2 \mathrm{H}_{2} \mathrm{O}$ & $6(6.1)$ \\
\hline & 2nd & $170-349$ & 250 & $1 \frac{1}{2} \mathrm{Cl}_{2}+2 \mathrm{H}_{2}$ & $19(18.7)$ \\
\hline & $3 \mathrm{rd}$ & $349-587$ & 530 & $\mathrm{CO}+\mathrm{NH}_{3}+\mathrm{NO}+\mathrm{N}_{2}+7 \mathrm{C}_{2} \mathrm{H}_{2}$ & $50(48.2)$ \\
\hline & Residue & $587-700$ & & $2 \mathrm{CuO}$ & $25(26.9)$ \\
\hline \multirow{4}{*}{ IV } & $1 \mathrm{st}$ & $39-180$ & 62 & $\mathrm{NO}+3 \mathrm{H}_{2}$ & $6.7(6.7)$ \\
\hline & 2nd & $180-335$ & 265 & $3 \mathrm{C}_{2} \mathrm{H}_{2}$ & $14.7(14.4)$ \\
\hline & 3rd & $335-552$ & 440 & $2 \mathrm{C}_{2} \mathrm{H}_{2}+\mathrm{NH}_{3}+\mathrm{N}_{2}+1 \frac{1}{2} \mathrm{Cl}_{2}$ & $38.6(37.6)$ \\
\hline & Residue & $552-700$ & & $2 \mathrm{ZnO}+$ carbon residue & $40(41.1)$ \\
\hline
\end{tabular}




\subsubsection{Nickel(II) Complex II}

The Ni(II) complex undergoes three main thermal degradation phases. The first step in the decomposition has a mass loss of $7 \%$ (calc. $=6.3 \%$ ) referring to the loss of two uncoordinated water molecules and two hydrogen gas molecules within the $38-168{ }^{\circ} \mathrm{C}$ temperature range. The second degradation phase within the $168-449^{\circ} \mathrm{C}$ temperature range with a $57.1 \%$ observed loss in weight (calc. $=55.9 \%$ ) points to chloride, ammonia, water, nitrogen oxide, nitrogen gas and hydrogen gas molecule losses. The final step in the decomposition process was a $29.3 \%$ mass loss (calc. $=28.8 \%$ ) corresponding to the loss of seven acetylene gas molecules. $2 \mathrm{NiO}$ molecules are the final residue whent eh complex is heated to $700{ }^{\circ} \mathrm{C}$.

\subsubsection{Copper(II) Complex III}

The thermal degradation of $\mathrm{Cu}(\mathrm{II})$ the complex occurs in three decomposition phases with DTG $\mathrm{max}_{\max }=85\left(40-170^{\circ} \mathrm{C}\right), 250\left(170-349.5^{\circ} \mathrm{C}\right)$ and $530\left(349.5-587^{\circ} \mathrm{C}\right)$. The first phase with an observed mass loss of $6 \%($ calc. $=6.1 \%$ ) correspond to the loss of two water molecules with a temperature maximum $\mathrm{DTG}_{\max }=85^{\circ} \mathrm{C}$. The second and third degradation phases with mass losses (obs. $=94 \%$, calc. $=99.9 \%$ ) suggesting the loss of five water molecules, ammonia gas, chloride, nitrogen, hydrogen, carbon oxide, acetylene, and nitrogen oxide gas molecules occur at the maximum temperatures of 250 and $530{ }^{\circ} \mathrm{C}$. $\mathrm{CuO}$ is the final residue.

\subsubsection{Zinc(II) Complex IV}

In the $\mathrm{Zn}(\mathrm{II})$ complex, thermal decomposition takes place in three main stages with $\mathrm{DTG}_{\max }=62\left(39-180^{\circ} \mathrm{C}\right), 265\left(180-335{ }^{\circ} \mathrm{C}\right), 440\left(180-335^{\circ} \mathrm{C}\right)$ and $440\left(335-552{ }^{\circ} \mathrm{C}\right)$, respectively. The first degradation phase with a $6.7 \%$ observed loss in weight (calc. $=6.7 \%$ ) is due to the loss of nitrogen oxide and hydrogen molecules with a temperature maximum DTG $\mathrm{Dax}_{\max }=62{ }^{\circ} \mathrm{C}$. The second thermal decomposition with a $14.7 \%$ loss in weight (calc $=14.4 \%$ ) coincides with the loss of three acetylene molecules in the $180-335^{\circ} \mathrm{C}$ temperature range. The final degradation phase with an observed mass loss of $40 \%$ (calc. $=41.1 \%$ ) corresponds to the loss of two acetylene, ammonia, nitrogen, and chlorine gas molecules in the $180-335{ }^{\circ} \mathrm{C}$ range. The residual product is $2 \mathrm{ZnO}$ up to $700{ }^{\circ} \mathrm{C}$.

\subsection{Kinetic Thermodynamic Parameters}

From Arrhenius plots between the rate of decomposition $(\ln K)$ and $1 / T$, kinetic values like the activation energy $\left(\mathrm{E}^{*}\right)$ were computed. The Coats-Redfern and Horowitz-Metzger equations were utilized to calculate other thermodynamic parameters such as the free energy $\Delta \mathrm{G}^{*}$, the enthalpy $\Delta \mathrm{H}^{*}$, and the entropy $\Delta \mathrm{S}^{*}$ of the process [22,23]. Since $\Delta \mathrm{G}^{*}, \Delta \mathrm{H}^{*}$, and $\Delta S^{*}$ are relevant to the greatest ratios, they are computed by the peak temperature Ts (Table 4). The activated prepared metal complexes were found to be more orderly structured than reactants and this was proved by the negative value of $\Delta \mathrm{S}^{*}$ [24].

\subsection{Biological Assessments}

From the data summarized in Table 5, we can conclude that diim metal complexes, especially the $\mathrm{Cu}$ (II) and $\mathrm{Zn}$ (II) ones, showed a potentially increase in antibacterial effect against B. subtilis, S. aureus, and E. coli compared to the diim ligand. On other hand, there was no antimicrobial effects for the diim ligand or its metal complexes towards the Gram positive bacterium Proteus vulgaris or towards the fungi Aspergillus flavus and Candida albicans.

In related investigations, almost all metal complexes show increased antibacterial effects compared to Schiff base ligands. These improvements are aacribed to the more prominent lipophilic nature of the complexes, which encourages the infiltration through the lipid layer as described previously [25]. Moreover, several reports mention the promising bacteriostatic and bactericidal effect of $\mathrm{Cu}$ (II) and $\mathrm{Zn}$ (II) complexes against a wide range of bacteria $[26,27]$. 
Table 4. Coats-Redfern (CR) and Horowitz-Metzger (HM) calculations for the MTSC and its metal complexes.

\begin{tabular}{|c|c|c|c|c|c|c|c|c|}
\hline \multirow{2}{*}{ Compound } & \multirow{2}{*}{ Stage } & \multirow{2}{*}{ Method } & \multicolumn{5}{|c|}{ Parameter } & \multirow{2}{*}{$\mathbf{r}$} \\
\hline & & & $\mathrm{E}^{*}\left(\mathrm{~J} \mathrm{~mol}^{-1}\right)$ & $A\left(s^{-1}\right)$ & $\Delta \mathrm{S}\left(\mathrm{J} \mathrm{mol}^{-1} \mathrm{~K}^{-1}\right)$ & $\Delta \mathrm{H}\left(\mathrm{J} \mathrm{mol}^{-1}\right)$ & $\Delta \mathrm{G}\left(\mathrm{J} \mathrm{mol}^{-1}\right)$ & \\
\hline \multirow{4}{*}{ diim } & 1st & CR & $1.98 \times 10^{-1}$ & $5.99 \times 10^{-9}$ & $-4.08 \times 10^{2}$ & $-4.85 \times 10^{3}$ & $2.33 \times 10^{5}$ & 0.9654 \\
\hline & & $\mathrm{HM}$ & $1.34 \times 10^{3}$ & $1.04 \times 10^{-4}$ & $-3.27 \times 10^{2}$ & $-3.50 \times 10^{3}$ & $1.87 \times 10^{5}$ & 0.9168 \\
\hline & 2nd & CR & $1.74 \times 10^{-1}$ & $3.42 \times 10^{-9}$ & $-4.16 \times 10^{2}$ & $-7.26 \times 10^{3}$ & $3.56 \times 10^{5}$ & 0.9983 \\
\hline & & $\mathrm{HM}$ & $2.21 \times 10^{3}$ & $7.87 \times 10^{-5}$ & $-3.32 \times 10^{2}$ & $-5.05 \times 10^{3}$ & $2.85 \times 10^{5}$ & 0.9907 \\
\hline \multirow{4}{*}{ I } & 1st & CR & $6.49 \times 10^{-2}$ & $6.99 \times 10^{-9}$ & $-4.04 \times 10^{2}$ & $-3.73 \times 10^{3}$ & $1.78 \times 10^{5}$ & 0.9268 \\
\hline & & $\mathrm{HM}$ & $5.69 \times 10^{2}$ & $6.62 \times 10^{-5}$ & $-3.28 \times 10^{2}$ & $-3.16 \times 10^{3}$ & $1.44 \times 10^{5}$ & 0.9974 \\
\hline & 2nd & $\mathrm{CR}$ & $1.89 \times 10^{-1}$ & $4.73 \times 10^{-9}$ & $-4.11 \times 10^{2}$ & $-5.31 \times 10^{3}$ & $2.57 \times 10^{5}$ & 0.9154 \\
\hline & & $\mathrm{HM}$ & $1.36 \times 10^{3}$ & $8.63 \times 10^{-5}$ & $-3.29 \times 10^{2}$ & $-3.95 \times 10^{3}$ & $2.06 \times 10^{5}$ & 0.9695 \\
\hline \multirow{6}{*}{ II } & 1st & CR & $1.70 \times 10^{-1}$ & $1.24 \times 10^{-8}$ & $-3.98 \times 10^{2}$ & $-3.02 \times 10^{3}$ & $1.41 \times 10^{5}$ & 0.9115 \\
\hline & & $\mathrm{HM}$ & $3.79 \times 10^{2}$ & $6.53 \times 10^{-5}$ & $-3.27 \times 10^{2}$ & $-2.64 \times 10^{3}$ & $1.16 \times 10^{5}$ & 0.9901 \\
\hline & 2nd & CR & $2.50 \times 10^{-1}$ & $7.26 \times 10^{-10}$ & $-4.25 \times 10^{2}$ & $-4.73 \times 10^{3}$ & $2.37 \times 10^{5}$ & 0.9700 \\
\hline & & $\mathrm{HM}$ & $1.62 \times 10^{3}$ & $1.41 \times 10^{-4}$ & $-3.24 \times 10^{2}$ & $-3.11 \times 10^{3}$ & $1.81 \times 10^{5}$ & 0.9087 \\
\hline & 3 rd & CR & $1.16 \times 10^{-1}$ & $4.44 \times 10^{-9}$ & $-4.10 \times 10^{2}$ & $-6.68 \times 10^{3}$ & $3.25 \times 10^{5}$ & 0.9116 \\
\hline & & $\mathrm{HM}$ & $1.41 \times 10^{3}$ & $5.41 \times 10^{-5}$ & $-3.30 \times 10^{2}$ & $-5.27 \times 10^{3}$ & $2.64 \times 10^{5}$ & 0.9949 \\
\hline \multirow{4}{*}{ III } & 1 st & CR & $1.37 \times 10^{-1}$ & $7.06 \times 10^{-9}$ & $-4.05 \times 10^{2}$ & $-3.85 \times 10^{3}$ & $1.84 \times 10^{5}$ & 0.9135 \\
\hline & & $\mathrm{HM}$ & $7.20 \times 10^{2}$ & $8.11 \times 10^{-5}$ & $-3.27 \times 10^{2}$ & $-3.13 \times 10^{3}$ & $1.48 \times 10^{5}$ & 0.9637 \\
\hline & 2nd & $\mathrm{CR}$ & $9.40 \times 10^{-2}$ & $2.04 \times 10^{-9}$ & $-4.19 \times 10^{2}$ & $-6.43 \times 10^{3}$ & $3.18 \times 10^{5}$ & 0.9899 \\
\hline & & $\mathrm{HM}$ & $1.72 \times 10^{3}$ & $7.52 \times 10^{-5}$ & $-3.32 \times 10^{2}$ & $-4.71 \times 10^{3}$ & $2.52 \times 10^{5}$ & 0.9957 \\
\hline \multirow{4}{*}{ IV } & $1 s t$ & $\mathrm{CR}$ & $3.82 \times 10^{-2}$ & $2.25 \times 10^{-9}$ & $-4.14 \times 10^{2}$ & $-3.84 \times 10^{3}$ & $1.88 \times 10^{5}$ & 0.9024 \\
\hline & & $\mathrm{HM}$ & $5.47 \times 10^{2}$ & $5.92 \times 10^{-5}$ & $-3.30 \times 10^{2}$ & $-3.30 \times 10^{3}$ & $1.49 \times 10^{5}$ & 0.9983 \\
\hline & 2nd & CR & $1.02 \times 10^{-1}$ & $3.09 \times 10^{-9}$ & $-4.15 \times 10^{2}$ & $-6.14 \times 10^{3}$ & $3.00 \times 10^{5}$ & 0.9647 \\
\hline & & $\mathrm{HM}$ & $1.57 \times 10^{3}$ & $7.44 \times 10^{-5}$ & $-3.32 \times 10^{2}$ & $-4.57 \times 10^{3}$ & $2.40 \times 10^{5}$ & 0.9926 \\
\hline
\end{tabular}

Table 5. Biological evaluations for diim ligand and its metal complexes at $10 \mathrm{mg}$.

\begin{tabular}{|c|c|c|c|c|c|c|}
\hline \multirow{2}{*}{ Compound } & \multicolumn{2}{|c|}{ Gram-Positive Bacteria } & \multicolumn{2}{|c|}{ Gram-Negative Bacteria } & \multicolumn{2}{|c|}{ Fungi } \\
\hline & B. subtillus & S. aureus & E. coli & Proteus vulgaris & Aspergillus flavus & Candida albicans \\
\hline diim & 9 & 12 & 10 & NA & NA & NA \\
\hline $\mathrm{I}$ & 10 & 10 & 11 & NA & NA & NA \\
\hline II & 12 & 12 & 13 & NA & NA & NA \\
\hline III & 18 & 18 & 12 & NA & NA & NA \\
\hline IV & 13 & 13 & NA & NA & NA & NA \\
\hline Gentamicin & 26 & 24 & 30 & 25 & - & - \\
\hline Ketoconazole & - & - & - & - & 16 & 20 \\
\hline
\end{tabular}

\subsection{Molecular Docking}

Docking calculations were done for a diim protein model after merging the nonpolar hydrogen atoms, defining rotatable bonds, adding Gasteiger charges, and other analytical parameters with the assistance of the AutoDock tools [28,29]. The docking simulation was accomplished by the Solis and Wets local search method and a Lamarckian genetic algorithm [30]. The docking survey output has been carried between the 3hb5oxidoreductase (breast cancer) protein and 401v-protein binding (kidney cancer) against the diim free ligand. The results are summarized in Table 6. Diim free ligand displayed good binding interactions with the amino acids of the protein molecules with binding reaction energy values of -7.23 and $-2.87 \mathrm{kcal} \mathrm{mol}^{-1}$ for the $3 h b 5$-oxidoreductase protein (Figure 8A) and 4o1v-protein (Figure 8B), respectively. It can be concluded that the free diim ligand can bind with active positions in 3hb5-oxidoreductase protein and 4o1v-protein and has a great binding affinity towards them. 
Table 6. Docking calculations for the diim free ligand.

\begin{tabular}{ccccccc}
\hline $\begin{array}{c}\text { Est. Free Energy of } \\
\text { Binding }\end{array}$ & $\begin{array}{c}\text { Est. Inhibition } \\
\text { Constant, Ki }\end{array}$ & $\begin{array}{c}\text { vdW + Hbond } \\
\text { desolv Energy }\end{array}$ & $\begin{array}{c}\text { Electrostatic } \\
\text { Energy }\end{array}$ & $\begin{array}{c}\text { Total Intermolec. } \\
\text { Energy }\end{array}$ & Frequency & $\begin{array}{c}\text { Interact. } \\
\text { Surface }\end{array}$ \\
\hline & & Results of TSC against 3hb5-Oxidoreductase & \\
\hline$-7.23 \mathrm{kcal} / \mathrm{mol}$ & $5.03 \mathrm{uM}$ & $-8.88 \mathrm{kcal} / \mathrm{mol}$ & $-0.09 \mathrm{kcal} / \mathrm{mol}$ & $-8.97 \mathrm{kcal} / \mathrm{mol}$ & $10 \%$ & 858.354 \\
\hline \multicolumn{7}{c}{ Results of TSC against $4 \mathrm{o} 1 \mathrm{v}-$ Protein } \\
\hline$-2.87 \mathrm{kcal} / \mathrm{mol}$ & $7.86 \mathrm{mM}$ & $-5.15 \mathrm{kcal} / \mathrm{mol}$ & $-0.09 \mathrm{kcal} / \mathrm{mol}$ & $-5.24 \mathrm{kcal} / \mathrm{mol}$ & $10 \%$ & 587.943 \\
\hline
\end{tabular}
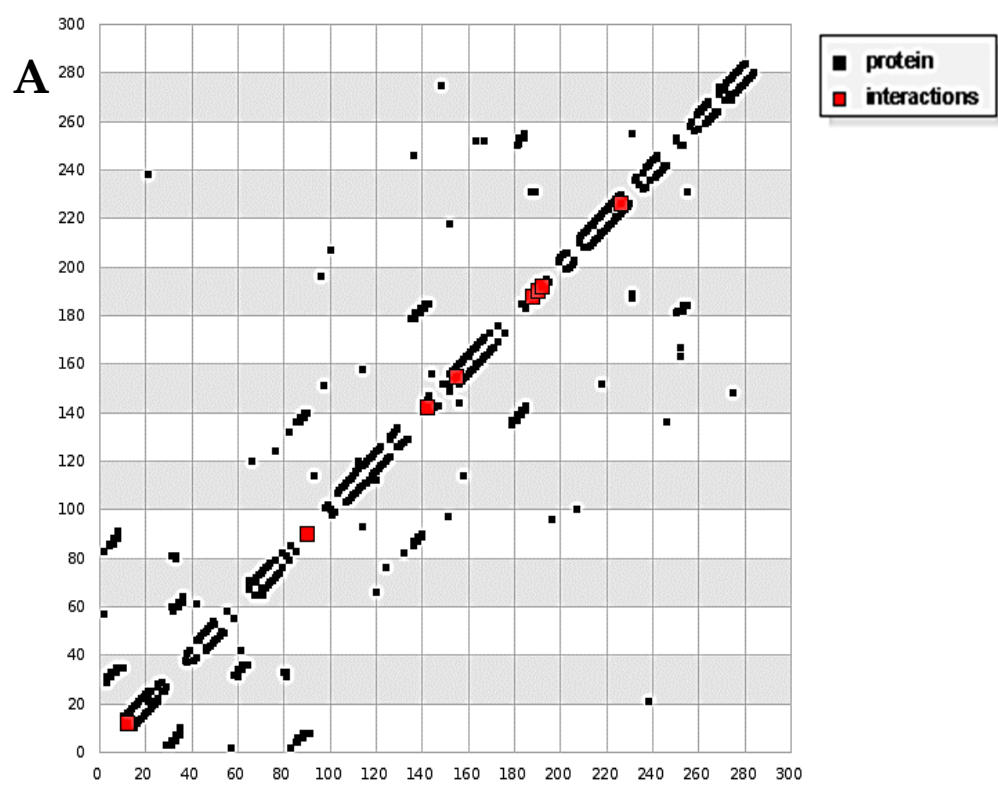

B

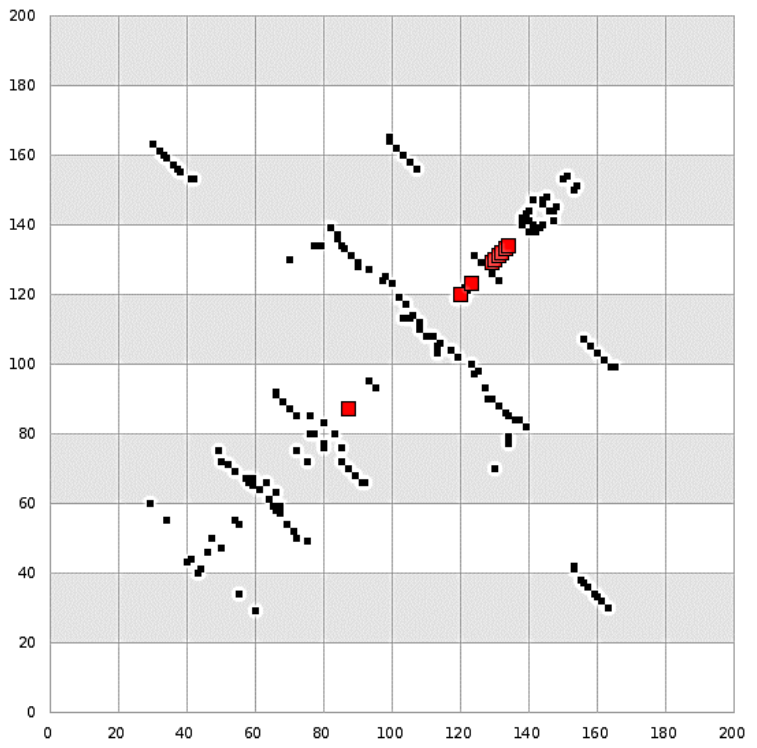

Figure 8. (A) HB plot of diim ligand against 3hb5-oxidoreductase protein and (B) HB plot of diim ligand against 4o1v-protein binding.

\section{Conclusions}

In this study, four different metal [Cu(II), Ni(II), Zn(II), and Co(II) ] complexes of diim ligand in a (2:1) metal to ligand ratio were prepared and characterized. The free ligand and its metal complexes were studied by various methods such as elemental analysis, electronic spectroscopy, FTIR, ${ }^{1} \mathrm{H}-\mathrm{NMR}$, and mass spectroscopy. From the FTIR spectra, it was found that the coordination process took place via the nitrogen atom of the azomethine group and 
the oxygen atom of the hydroxyl group for the first metal ion, while, the second one formed a coordination bond with the oxygen atom of the phenol group and the other nitrogen atom of azomethine group forming binuclear (2:1) complexes. All complexes display an octahedral geometry except for $\mathrm{Zn}(\mathrm{II})$ which has a tetrahedral configuration. Thermal degradation for the free ligand and its metal complexes was studied by (TG/DrTGA) analysis in a nitrogen atmosphere. The conductivity values verified the nonelectrolyte behavior of all the complexes. The antibacterial effects of the diim metal complexes, especially the $\mathrm{Cu}(\mathrm{II})$ and $\mathrm{Zn}(\mathrm{II})$ ones, exhibit a potential antibacterial effect against $B$. subtilis, S. aureus, and E. coli higher than that of the diim ligand. Finally, from a molecular docking study, the diim ligand can bind with the active positions of the breast cancer $3 h b 5$-oxidoreductase protein and the kidney cancer 4o1v-protein and means it has a great binding affinity towards them.

Supplementary Materials: The following are available online at https:/ / www.mdpi.com/2073-435 2/11/3/300/s1, Figure S1: Mass spectrum fragmentations of cobalt(II) complex; Figure S2: Mass spectrum fragmentations of nickel(II) complex; Figure S3: Mass spectrum fragmentations of copper(II) complex; Figure S4: ass spectrum fragmentations of Zink(II) complex.

Author Contributions: Conceptualization, A.A.M.B., I.M.E.-D. and M.S.R.; methodology, A.A.M.B., N.H., R.Z. and M.S.R.; software, N.H. and R.Z.; validation, A.G., W.F.A. and M.S.R.; formal analysis, A.G., W.F.A., A.A.M.B., A.M.N. and I.M.E.-D.; investigation, A.G., W.F.A., R.Z. and M.S.R.; resources, A.A.M.B., I.M.E.-D., N.H. and M.S.R.; data curation, N.H., R.Z. and M.S.R.; writingoriginal draft preparation, A.G., A.A.M.B., I.M.E.-D. and M.S.R.; writing-review and editing, A.G., A.M.N. and M.S.R.; visualization, W.F.A. and R.Z.; supervision, M.S.R.; project administration, A.G.; funding acquisition, A.G. and W.F.A. All authors have read and agreed to the published version of the manuscript.

Funding: This research was funded by Taif University Researchers Supporting Project number (TURSP-2020/39), Taif University, Taif, Saudi Arabia.

Institutional Review Board Statement: The experiment did not require ethical approval.

Informed Consent Statement: Not applicable.

Data Availability Statement: The data used to support the findings of this study are included within the article.

Acknowledgments: The authors' appreciate Taif University Researchers Supporting Project number (TURSP-2020/39), Taif University, Taif, Saudi Arabia.

Conflicts of Interest: The authors declare no conflict of interest.

\section{References}

1. Verma, G.; Marella, A.; Shaquiquzzaman, M.; Akhtar, M.; Ali, M.R.; Alam, M.M. A review exploring biological activities of hydrazones. J. Pharm. Bioallied. Sci. 2014, 6, 69-80. [PubMed]

2. Uppal, G.; Bala, S.; Kamboj, S.; Saini, M. Therapeutic review exploring antimicrobial potential of hydrazones as promising lead. Der Pharma Chem. 2011, 3, 250-268.

3. Rollas, S.; Küçükgüzel, S.G. Biological Activities of Hydrazone Derivatives. Molecules 2007, 12, 1910-1939. [CrossRef]

4. Narang, R.; Narasimhan, B.; Sharma, S. A review on biological activities and chemical synthesis of hydrazide derivatives. Curr. Med. Chem. 2012, 19, 569-612. [CrossRef] [PubMed]

5. Negi, V.J.; Sharma, A.K.; Negi, J.S.; Ra, V. Biological activities of hydrazone derivatives in the new millennium. Int. J. Pharm. Chem. 2012, 4, 100-109. [CrossRef]

6. Belskaya, N.P.; Dehaen, W.; Bakulev, V.A. Synthesis and properties of hydrazones bearing amide, thioamide and amidine functions. Arch. Org. Chem. 2010, 1, 275-332. [CrossRef]

7. Xavier, A.J.; Thakur, M.; Marie, J.M. Synthesis and spectral characterisation of hydrazone based 14-membered octaaza macrocyclic Ni(II) complexes. J. Chem. Pharm. Res. 2012, 4, 986-990.

8. Banerjee, S.; Mondal, S.; Chakraborty, W.; Sen, S.; Gachhui, R.; Butcher, R.J. Syntheses, X-ray crystal structures, DNA binding, oxidative cleavage activities and antimicrobial studies of two Cu (II) hydrazone complexes. Polyhedron 2009, 28, 2785-2793. [CrossRef]

9. Shakdofa, M.; Shtaiwi, M.; Morsy, N.M.; Abdel-Rassel, T.M.A. Metal complexes of hydrazones and their biological, analytical and catalytic applications: A review. Main Group Chem. 2014, 13, 187-218. [CrossRef] 
10. Issa, Y.M.; Issa, R.M.; El-Latif, S.A.A.; El-Salam, H.A.A. Structural Studies of Cu(II) Chelates with Some Arylidene Derivatives of Benzilic Hydrazide. Mon. Fur Chem. 1998, 129, 19-29. [CrossRef]

11. Sharma, A.; Mehta, T.; Shah, M.K. Synthesis and spectral studies of transition metal complexes supported by NO-bidentate Schiff-Base ligand. Der Chem. Sin. 2013, 4, 141-146.

12. Kumar, R.; Singh, K.; Srivastava, R.; Kamalasanan, M.N. Advanced Nanomaterials and Emerging Engineering Technologies (ICANMEET). In Proceedings of the 2013 International Conference, Chennai, India, 24-26 July 2013; pp. 520-523.

13. Kim, S.M.; Kim, J.S.; Sin, D.M.; Kim, Y.G.; Ha, Y.G. Synthesis and application of the novel azomethine metal complexes for the organic electroluminescent devices. Bull. Korean Chem. Soc. 2001, 22, 743-747.

14. Bushuev, M.B.; Selivanov, B.A.; Pervukhina, N.V.; Naumov, D.Y.; Rakhmanova, M.I.; Sheludyakova, L.A.; Tikhonov, A.Y.; Larionov, S.V. Luminescent zinc (II) and cadmium (II) complexes based on 2-(4, 5-dimethyl-1 H-imidazol-2-yl) pyridine and 2-(1-hydroxy-4, 5-dimethyl-1 H-imidazol-2-yl) pyridine. Russ. J. Gen. Chem. 2012, 82, 1859-1868. [CrossRef]

15. Yang, C.L.; Luo, J.X.; Ma, J.Y.; Lu, M.G.; Liang, L.Y.; Tong, B.H. Synthesis and photoluminescent properties of four novel trinuclear europium complexes based on two tris- $\beta$-diketones ligands. Dyes Pigm. 2012, 92, 696-704. [CrossRef]

16. Chattopadhyay, T.; Mukherjee, M.; Banu, K.S.; Banerjee, A.; Suresh, E.; Zangrando, E.; Das, D. Mono-and dinuclear Zn (II) complexes of Schiff-base ligands: Syntheses, characterization and studies of photoluminescence. J. Coord. Chem. 2009, 62, 967-979. [CrossRef]

17. El-Habeeb, A.A.; Refat, M.S. Synthesis, structure interpretation, antimicrobial and anticancer studies of tranexamic acid complexes towards Ga (III), W (VI), Y (III) and Si (IV) metal ions. J. Mol. Struct. 2019, 1175, 65-72. [CrossRef]

18. Nakamoto, K. Infrared and Raman Spectra of Inorganic and Coordination Compounds: Part A: Theory and Applications in Inorganic Chemistry, 6th ed.; Wiley: New York, NY, USA, 2008.

19. Chandra, S.; Gupta, K. Twelve-, fourteen- and sixteen-membered macrocyclic ligands and a study of the effect of ring size on ligand field strength. Trans. Met. Chem. 2002, 27, 329-332. [CrossRef]

20. Lever, A.B.P. Crystal Field Spectra. In Inorganic Electronic Spectroscopy, 1st ed.; Elsevier: Amsterdam, The Netherlands, 1968.

21. Lever, A.B.P. Inorganic Electronic Spectroscopy, 2nd ed.; Elsevier: Amsterdam, The Netherlands, 1984.

22. Coats, A.W.; Redfern, J.P. Kinetic Parameters from Thermogravimetric Data. Nature 1964, 201, 68-69. [CrossRef]

23. Horowitz, H.W.; Metzger, G. A new analysis of thermogravimetric traces. Anal. Chem. 1963, 35, 1464. [CrossRef]

24. Chourasia, P.; Suryesh, K.K.; Mishra, A.P. Synthesis and structural investigation of some mixed-ligand selenito complexes of cobalt (II). Proc. Indian Acad. Sci. 1993, 105, 173-189.

25. Claudel, M.; Schwarte, J.V.; Fromm, K.M. New Antimicrobial Strategies Based on Metal Complexes. Chemistry 2020, 2, 849-899. [CrossRef]

26. Zalevskaya, O.; Gur'eva, Y.; Kutchin, A.; Hansford, K.A. Antimicrobial and Antifungal Activities of Terpene-Derived Palladium Complexes. Antibiotics 2020, 9, 277. [CrossRef] [PubMed]

27. Sheikhshoaie, I.; Lotfi, N.; Sieler, J.; Krautscheid, H.; Khaleghi, M. Synthesis, structures and antimicrobial activities of nickel (II) and zinc (II) diaminomaleonitrile-based complexes. Transit. Met. Chem. 2018, 43, 555-562. [CrossRef]

28. Bikadi, Z.; Hazai, E. Application of the PM6 semi-empirical method to modeling proteins enhances docking accuracy of AutoDock. J. Cheminformatics 2009, 1, 15. [CrossRef] [PubMed]

29. Morris, G.M.; Goodsell, D.S.; Halliday, R.S.; Huey, R.; Hart, W.E.; Belew, R.K.; Olson, A.J. Automated docking using a Lamarckian genetic algorithm and an empirical binding free energy function. J. Comput. Chem. 1998, 19, 1639-1662. [CrossRef]

30. Solis, F.J.; Wets, R.J.B. Minimization by random search techniques. Math. Oper. Res. 1981, 6, 19-30. [CrossRef] 